\title{
Pendampingan Lesson Study Untuk Meningkatkan Kompetensi Guru Sekolah Dasar di KKG Gugus Sungai Miai Banjarmasin dalam Menerapkan Pendekatan Saintifik Menggunakan Kurikulum 2013
}

\author{
Dessy Noor Ariani \\ Program Studi Pendidikan Guru Madrasah Ibtidaiyah, \\ Fakultas Studi Islam, Universitas Islam Kalimantan MAB \\ dessynoorarianii@gmail.com
}

\begin{abstract}
ABSTRAK
Kegiatan pengabdian ini bertujuan untuk memberikan pemahaman yang aplikatif kepada guru-guru kelas di KKG SD Gugus Sungai Miai Banjarmasin tentang pendekatan saintifik. Pendekatan ini perlu disampaikan mengingat pendekatan ini relevan dengan pelaksanaan kurikulum 2013 dan berbagai hasil penelitian menunjukkan bahwa penggunaannya dapat meningkatkan kualitas pembelajaran sehingga hasil pembelajaran lebih bermakna. Adapun bentuk pelaksanaan pengabdian ini adalah menggunakan tahapan lesson study, yaitu: Plan (perencanaan pembelajaran), Do (pelaksanaan dan pengamatan pembelajaran), dan See (refleksi pembelajaran).
\end{abstract}

\section{Kata kunci: Lesson Study, Pendekatan Saintifik, K13, Guru SD}

PENDAHULUAN
Pendekatan scientific pertama kali diperkenalkan ke ilmu pendidikan Amerika pada akhir abad ke-19, sebagai penekanan pada metode laboratorium formalistik yang mengarah pada fakta-fakta ilmiah. Pendekatan scientific ini memiliki karakteristik "doing science". Pendekatan ini memudahkan guru atau pengembang kurikulum untuk memperbaiki proses pembelajaran, yaitu dengan memecah proses ke dalam langkahlangkah atau tahapan-tahapan secara terperinci yang memuat instruksi untuk siswa melaksanakan kegiatan pembelajaran.

Menurut Hosnan (2014) dalam pendekatan saintifik terdapat beberapa prinsip dalam kegiatan pembelajaran, yaitu: a) Pembelajaran berpusat pada siswa; b) Pembelajaran membentuk konsep diri siswa; c) Pembelajaran terhindar dari verbalisme; d) Pembelajaran memberikan kesempatan pada siswa untuk mengasimilasi dan mengakomodasi konsep, hukum, dan prinsip; e) Pembelajaran mendorong terjadinya peningkatan kemampuan berpikir peserta didik; f) Pembelajaran meningkatkan motivasi belajar peserta didik dan motivasi mengajar guru; g) Memberikan kesempatan kepada peserta didik untuk melatih kemampuan dalam komunikasi; dan h) Adanya proses validasi terhadap konsep, hukum, dan prinsip yang dikonstruksi peserta didik dalam struktur kognitifnya.

Hal ini sejalan dengan Permendikbud Nomor 103 Tahun 2014 yang mengisyaratkan perlunya proses pembelajaran dengan menggunakan pendekatan saintifik atau ilmiah yang dituangkan ke dalam kurikulum 2013. Pendekatan saintifik (scientific approach) diyakini sebagai titian emas perkembangan dan pengembangan sikap, keterampilan, dan pengetahuan peserta didik dalam pendekatan atau proses kerja yang memenuhi kriteria ilmiah. Dalam konsep pendekatan scientific yang disampaikan oleh Kementrian Pendidikan dan Kebudayaan, dipaparkan minimal ada 7 (tujuh) kriteria dalam pendekatan scientific. Ketujuh kriteria tersebut adalah sebagai berikut : 1) Materi pembelajaran berbasis pada fakta atau fenomena yang dapat dijelaskan dengan logika atau penalaran tertentu ; bukan sebatas kira - kira, khayalan, legenda, atau dongeng semata; 2) Penjelasan guru, respon siswa, dan interaksi edukatif guru dan siswa terbebas dari prasangka yang serta - merta, pemikiran subjektif, atau penalaran yang menyimpang dari alur berpikir logis; 3) Mendorong dan menginspirasi siswa berpikir secara kritis, analitis, dan tepat dalam mengidentifikasi, memahami, memecahkan masalah, dan mengaplikasikan materi pembelajaran; 4) Mendorong dan menginspirasi siswa mampu berpikir hipotetik 
dalam melihat perbedaan, kesamaan, dan tautan satu sama lain dari materi pembelajaran; 5) Mendorong dan menginspirasi siswa dalam memahami, menerapkan, dan mengembangkan pola berpikir yang rasional dan objektif dalam merespon materi pembelajaran; 6) Berbasis pada konsep, teori, dan fakta empiris yang dapat dipertanggungjawabkan; dan 7) Tujuan pembelajaran dirumuskan secara sederhana dan jelas, tetapi menarik sistem penyajiannya.

Kenyataan di lapangan hasil uji kompetesi guru (UKG) di Kalimantan Selatan tahun 2015 bidang kompetensi pedagogik dan profesional menunjukkan bahwa nilai rata-rata guru masih di bawah standar kompetensi minimum (SKM), yaitu 53,15. Sementara standar kompetensi minimum guru pada ujian kompetensi guru adalah 55(Kemdikbud RI, 2016).

Hasil perbincangan peneliti dengan pengawas Madrasah Ibtidaiyah dan Sekolah Dasar mengungkapkan bahwa salah satu faktor yang mempengaruhi rendahnya kompetensi guru tersebut adalah kurangnya pemahaman dan penguasaan guru terhadap strategi pembelajaran aktif atau pendekatanpendekatan pembelajaran yang berpusat kepada siswa yang merupakan ciri dari pembelajaran K13. Hal tersebut membuat materi pelajaran yang semestinya tidak terlalu sulit menjadi semakin sulit, dan materi yang seharusnya bermakna bagi kehidupan siswa menjadi kurang bermakna dan kurang dipahami siswa secara utuh. Hal tersebut mengakibatkan proses pembelajaran bersifat pasif, mendengarkan ceramah guru, dan kurang memperhatikan perkembangan berpikir kritis siswa, dan kreatifitas siswa dalam menemukan, dan membangun konsep pengetahuannya.

Adapun menurut hasil temuan penulis, beberapa masalah terkait pembelajaran di K13 adalah sebagai berikut: 1) Guru-guru SD/MI masih belum mengetahui lesson studi. Dengan guru-guru SD melaksanakan lesson studi dengan cara mutual teaching diharapkan dapat melakukan inovasi pembelajaran, melakukan diskusi dengan teman sejawat yang berhubungan dengan proses pembelajaran dan lebih berani menjadi guru model saat mutual teaching sehingga dapat meningkatkan kompetensi guru dalam mengajar. 2) Kurangnya pengetahuan dan keterampilan guru tentang pembelajaran K13 yang identik dengan pendekatan saintifik, terutama pada langkah bertanya dan penalaran. 3) Institute of Education Reform menyatakan bahwa buku pelajaran menyajikan materi yang terlalu padat dan penyajiannya kurang sesuai dengan pola pikir anak sehinga guru perlu menggunakan pendekatan pembelajaran yang bermakna

Melihat kenyataan tersebut, tampaknya perlu dilakukan suatu kegiatan pendampingan terhadap guru-guru SD/MI agar mereka mampu meningkatkan pemahaman dan keterampilan mereka dalam menggunakan strategi dan pendekatan pembelajaran yang menjadikan pembelajaran yang berorientasi pada pengalaman sehari-hari proses pembelajarannya lebih aktif dan menarik.

Hal ini dilakukan melalui kegiatan pengabdian pada masyarakat (P2M) sebagai salah satu kegiatan Tri Dharma Perguruan Tinggi yang mutlak dilakukan oleh dosen. Kegiatan P2M ini adalah berbentuk pendampingan guru-guru kelas di tingkat SD dalam menerapkan pendekatan Saintifik melalui lesson studi. Adapun manfaat dari lesson study yaitu meningkatnya pengetahuan guru tentang materi ajar dan pembelajaran, meningkatnya pengetahuan guru tentang cara mengobservasi aktivitas belajar siswa, menguatnya hubungan kolegalitas baik antar guru maupun dengan observer lainnya, menguatnya hubungan antara pelaksana pembelajaran sehari-hari dengan tujuan pembelajaran jangka panjang, meningkatnya motivasi guru untuk senantiasa berkembang, dan meningkatnya kualitas pembelajaran (Dadan, 2007).

Melalui implementasi Lesson Study juga memungkinkan 'gebyar' supervisi akademik. Peningkatan jumlah, frekuensi, dan kualitas supervisi akademik bagi Kepala Sekolah akan termotivasi dalam bentuk 'pendampingan'. Pendampingan akan lebih memotivasi Kepala Sekolah dan guru untuk sinergi dalam pengelolaan pembelajaran. Adapun manfaat dari lesson study yaitu meningkatnya pengetahuan guru tentang materi ajar dan pembelajaran, meningkatnya pengetahuan guru tentang cara mengobservasi aktivitas belajar siswa, menguatnya hubungan kolegalitas baik antar guru maupun dengan observer lainnya, menguatnya hubungan antara pelaksana pembelajaran sehari-hari dengan tujuan pembelajaran jangka panjang, meningkatnya motivasi guru untuk senantiasa berkembang, dan meningkatnya kualitas pembelajaran.

\section{METODE KEGIATAN}

Kegiatan pengabdian kepada masyarakat ini ditujukan kepada Kelompok Kerja Guru 
(KKG) SD gugus Sungai Miai Banjarmasin. Setelah mengikuti kegiatan pengabdian ini guru-guru diharapkan termotivasi dan mampu menggunakan pendekatan saintifik sebagai salah satu pendekatan yang bisa digunakan pada pembelajaran K13.

Kegiatan pengabdian kepada masyarakat ini menggunakan metode lesson study. Sebelum melaksanakan lesson studi penulis melakukan sosialisasi terlebih dahulu tentang lesson study dan pendekatan saintifik. Adapun tahapan lesson study adalah plan, do, dan see. Secara teknis, ke tiga tahap tersebut dipaparkan sebagai berikut.

a. Plan (perencanaan pembelajaran)

Setelah sebelumnya melakukan telaah kurikulum serta merumuskan tujuan pembelajaran dan tujuan pengembangan siswa, langkah awal dalam rangkaian lesson study adalah merancang pembelajaran dengan pendekatan saintifik untuk mencapai tujuan dalam wujud perangkat pembelajaran, termasuk di antaranya Rencana Pelaksanaan Pembelajaran (RPP). Kegiatan ini dilakukan secara kolaboratif antara guru, pengawas SD dan pelaksana pengabdian kepada masyarakat.

b. Do (pelaksanaan dan pengamatan pembelajaran)

Langkah ini dimaksudkan untuk melaksanakan pembelajaran di kelas berdasarkan perangkat pembelajaran yang telah disiapkan sebelumnya. Kegiatan ini dilakukan oleh guru model yang dintunjuk dari salah seorang dari kelompok kerja guru yang terlibat dalam kegiatan perencanaan pembelajaran tersebut.

Bersamaan dengan pelaksanaan pembelajaran, dilakukan pula pengamatan terhadap pelaksanaan pembelajaran tersebut. Pengamatan ini dilakukan oleh teman sejawat dalam bidang ilmu serumpun atau mengajar pada tingkatan kelas yang sama, kepala sekolah SD, pengawas SD, dan pelaksana pengabdian kepada masayarakat. Pada saat melakukan pengamatan (see), perhatian difokuskan kepada perilaku siswa di kelas (bukan pada aktivitas mengajar guru).

c. See (refleksi pembelajaran)

Setelah melaksanakan pembelajaran dan mengamatinya, seluruh pihak yang terlibat dalam aktivitas pengamatan melakukan refleksi untuk mendiskusikan pembelajaran yang dikaji tersebut dan menyempurkannya, serta merencanakan pembelajaran berikutnya. Dalam tahap refleksi ini, pembahasan tidak dimaksudkan untuk mengomentari aktivitas guru ketika melaksanakan pembelajaran, melainkan lebih diarahkan pada hasil pengamatan terhadap perilaku siswa selama proses pembelajaran di kelas. Dengan demikian tidak ada komentar terhadap perilaku guru ketika mengajar, namun diharapkan berdasarkan refleksi pengamat terhadap perilaku siswa tersebut, guru model akan dapat merefleksi dirinya sendiri.

\section{HASIL \& PEMBAHASAN}

Hasil kegiatan pendampingan lesson study untuk meningkatkan kompetensi guru dalam menerapkan pendekatan saintifik menggunakan kurikulum 2013 terlaksana sesuai dengan rencana jadwal yang telah disusun dan hasil kegiatan tersebut dapat dijabarkan sebagai berikut:

Jumlah peserta yang hadir dalam kegiatan pelatihan ini adalah 20 orang guru. Adapun kegiatan yang dilakukan pada kegiatan pendampingan ini adalah sebagai berikut:

a. Penjelasan tentang Lesson Study (cukup satu kali)

b. Penjelasan tentang pendekatan saintifik (cukup satu kali)

c. Penyusunan jadwal Lesson Study, penentuan materi yang digunakan, guru model, moderator dan observer.

d. Pelaksanaan kegiatan Plan yang berisi kegiatan Penyusunan RPP, model pembelajaran, dan media pembelajaran bersama yang dilakukan oleh anggota lesson study, kepala sekolah SD, pengawas sekolah dan pelaksana pengabdian kepada masayarakat.

e. Pelaksanaan kegiatan Do di SDN Surgi Mufti 4 dengan guru model adalah Zainal Abidin, S.Pd. Pada kegiatan Do ini guru model membawakan materi tentang Kalor. Ada beberapa kegiatan yang dilakukan oleh guru model dalam proses pembelajarannya yaitu 1) menonton video tentang Kalor, 2) melakukan percobaan dengan menggunakan es batu, lilin, air, dan sendok untuk membuktikan bagaimana cara perambatan kalor, dan 3) pembuatan montase tentang perambatan kalor.

f. Pelaksaaan kegiatan See di SDN Surgi Mufti 4 yang membahas tentang perilaku siswa selama kegiatan Do. Dari kegiatan Do yang dilakasanakan ada beberapa poin yang dicatatat oleh observer, yaitu: 1) ada beberapa siswa yang kurang focus dalam menonton video, 2) saat pelaksanaan percobaan ada beberapa siswa yang bermain dengan alat percobaan, dan 3) 
saat sesi presentasi hasil diskusi siswa, beberapa kelompok menjawab dengan salah. Dari hasil diskusi guru model dan para observer disimpulkan beberapa solusi yaitu, 1) tidak menyuruh siswa menonton video sambil menulis isi video tersebut, 2) lebih cekatan dalam mengawasi siswa saat melakukan praktikum, jika perlu didampingi oleh guru pendamping, 3) memberikan penguatan terhadap siswa setelah menonton video.

Selama kegiatan, ada beberapa kendala yang terjadi seperti, ada beberapa peserta lesson study yang terlambat hadir sehingga mengganggu konsentrasi siswa dalam belajar, fasilitas yang kurang memadai berupa kurang nyaringnya volume dari microfon sehingga ada peserta yang kurang mendengar, tetapi hal ini masih bisa diatasi sehingga tidak terlalu mengganggu proses kegiatan. Selama acara kegiatan peserta pelatihan tampak aktif dan sangat tertarik dalam berdiskusi dan mengikuti kegiatan pendampingan Lesson Study dalam Menerapkan Pendekatan Saintifik Menggunakan Kurikulum 2013.
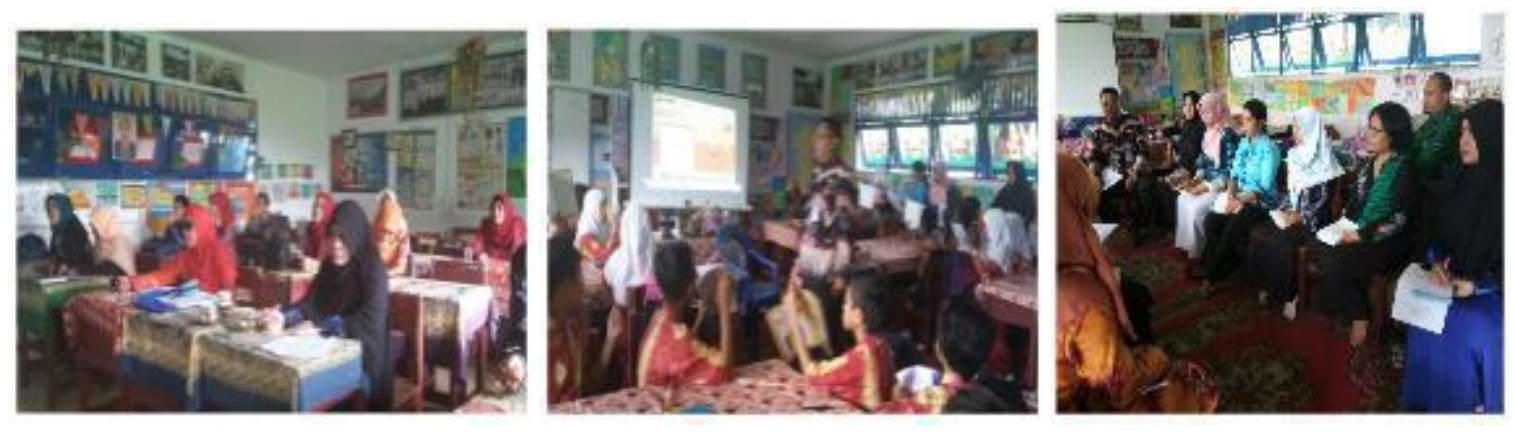

Gambar 1. Foto kegiatan Lesson Study

Pembinaan guru Sekolah Dasar berbasis lesson study ini telah dapat meningkatkan kemampuan guru dalam menerapkan berbagai strategi pembelajaran yang berpusat kepada siswa dan sikap guru dalam menggunakan berbagai strategi dalam pembelajaran. Di antara indikatornya adalah; a) Guru bekerjasama dalam merancang pembelajaran dan membuat RPP (Rencana Pelaksanaan Pembelajaran), b) Guru bekerjasama dalam membuat alat peraga atau media pembelajaran, c) Guru bekerjasama menggunakan strategi pembelajaran yang tepat, d) Guru berdiskusi tentang teknik menggunakan pendekatan saintifik dalam topic pembelajaran di kelas 4 dan 5, e) Guru berkolaborasi dalam memberikan hasil observasi tentang aktivitas siswa dan saran bagi kegiatan pembelajaran berikutnya. Hasil wawancara dengan guru diperoleh informasi bahwa mereka.

Hasil wawancara dengan guru diperoleh informasi bahwa mereka mengaku sangat senang terhadap pelaksanaan lesson study. Hal tersebut antara lain karena: guru model dapat belajar dari umpan balik yang diberikan oleh observer terkait aktivitas atau respon siswa terhadap model pembelajaran yang dipraktikkan, guru lebih mendalami karakteristik dan cara belajar siswa, guru terdorong untuk memperbaiki cara mengajarnya melalui pengamatan terhadap cara belajar siswa, dan guru dapat berbagai strategi dan teknik mengajar yang relevan dengan materi pembelajaran tertentu sehingga cukup baik dalam menciptakan mutual learning (saling belajar) di antara sesama guru.

Hal ini sejalan dengan Saito (2006) yang berpendapat bahwa; lesson study merupakan kegiatan pembelajaran yang bertujuan dalam meningkatkan kompetensi guru dan kualitas pembelajaran. Selanjutnya menurut Lewis (2002) juga berpendapat bahwa jika seorang guru ingin meningkatkan pembelajaran, salah satu caranya adalah guru harus berkolaborasi dengan guru lain dalam berbagai hal yang berkaitan dengan pembelajaran, yaitu dapat berupa membuat rencana pembelajaran; melaksanakan pembelajaran dan observasi; dan melakukan refleksi dan evaluasi terhadap pembelajaran yang dilakukan. Dengan kata lain lesson study, merupakan model pembinaan profesi pendidik melalui pengkajian pembelajaran secara kolaboratif dan berkelanjutan, berlandaskan prinsip-prinsip kolegialitas dan saling membantu dalam pembelajaran, untuk membangun komunitas belajar. 


\section{KESIMPULAN \& SARAN}

Berdasarkan hasil kegiatan pengabdian pada masyarakat yangberupa pendampingan guru-guru kelas di KKG SD Gugus Sungai Miai Banjarmasin dalam menerapkan pendekatan Saintifik melalui lesson study maka dapatdisimpulkan sebagai berikut.

1. Pendampingan kegiatan Lesson study berjalan dengan lancar berkat dukungan berbagai pihak.

2. Kegiatan pendampingan ini memberikan pengetahuan dan keterampilan guru tentang penerapan lesson study dan pembelajaran dengan pendekatan saintifk

3. Tingkat pemahaman peserta kegiatan tentang Lesson Study dan Pendekatan Pembelajaran Saintifk meningkat setelah diadakan kegiatan pendampingan ini.

Kegiatan Lesson study sebaiknya dilanjutkan secara terus menerus untuk meningkatkan kompetensi guru. Pengurus KKG dan Kepala Sekolah dapat menjadikan kegiatan Lesson Study sebagai kegiatan rutin untuk meningkatkan kompetensi guru

\section{DAFTAR PUSTAKA}

Arends, Richard. 2012. Learning to Teach: Nineth Edition. USA: McgrawHill Companies Inc.

Dadan dkk, 2007. Lesson Study. Materi pelatihan.

Hosnan, M. 2014. Pendekatan Saintifk dan Kontekstual dalam Pembelajaran Abad 21. Bogor: Ghalia Indonesia

Kemdikbud RI. (2016). Neraca Pendidikan Daerah 2016. Jakarta. Retrieved from

http://npd.data.kemdikbud.go.id/i ndex.php/

Kemdikbud. 2013. Pendekatan Scientific (Ilmiah) dalam Pembelajaran . Jakarta: Pusbangprodik

Lewis, Catherine C. 2002. Lesson study: A Handbook of Teacher-Led Instructional Change. Philadelphia, PA: Research for Better Schools, Inc.

Saito E. 2006. Development of school based in-service teacher training under the Indonesian Mathematics and Science Teacher Education Project. Improving Schools. Vol.9 (1): 4759. 